\title{
The Exploration of the Application of New Media in University Politics Education
}

\author{
Xinjie Qiao \\ Yellow river Conservancy Technical Institute, Kaifeng, China
}

\begin{abstract}
In the era of mobile internet, new media is increasingly becoming one of the carriers of ideological and political education in colleges and universities, and it brings opportunities to ideological and political education in colleges and universities. According to the characteristics of the application of new media, this paper gives full play to its advantages in ideological and political education, actively explores the countermeasures of ideological and political education in colleges and universities in the new media era, and promotes the integration of traditional advantages of ideological and political work with information technology. To create a new situation of ideological and political education in colleges and universities.
\end{abstract}

Keywords-ideological and political education; new media; application

\section{INTRODUCTION}

New media become more and more popular in the modern time, people are getting used to using new media to acquire knowledge. With the background of the diversity of network culture, people's ideas and ways of living have changed greatly. College students prefer to accept new things, and new media are popular with college students. Therefore, colleges and universities should combine the personality and characteristics of contemporary college students, and apply new media to stimulate students' interest in ideological and political knowledge in ideological and political education. It will improve the efficiency and quality of ideological and political teaching.

\section{Characteristics OF NEW MEdia ApPliCATION}

\section{A. It can Fully Reflect Students' Subjectivity}

The application of new media in ideological and political education fully combines information technology with traditional teaching to reflect students' subjectivity. At the same time, the application of new media can take advantage of the initiative of students, promote students to think more, more understanding. Ideological and political education is mainly to improve and influence the students' moral accomplishment and political level. The new media can play a good guiding effect on students, appropriately and timely influence, and stimulate students' interest in ideological and political knowledge.

\section{B. It can Enhance the Efficiency of Ideological and Political Education}

The new media can concretize and visualize abstract knowledge and concepts, which coincides with the characteristics of ideological and political education. For college students, the new media has a strong effectiveness and efficiency, in line with the acceptance of students, can fully attract the attention of students. Teachers use a large number of video, picture and text resources in the new media to carry out video teaching or case teaching, which can vividly and intuitively display knowledge to students, let students feel the knowledge directly, and enhance the vitality of ideological and political education. Intuition and visibility.

\section{The Fragmentation of Knowledge Acquisition}

The new media has completely changed people's way of obtaining and disseminating information, and the ways and carriers of knowledge and information have changed greatly, showing obvious fragmentation. Students use the new media to acquire knowledge, and everyone can present their views and opinions on the new media, presenting a new mode of communication.

\section{It can Enhance the Effectiveness of Ideological and Political Education}

The traditional ideological and political education often uses one-way indoctrination, students passively accept the contents of classroom education, neglecting students' needs and ability to accept, which easily leads to students' conflict and disgust, resulting in the effect of Ideological and political education greatly reduced. The new media has set up a new communication bridge between Ideological and political educators and students, opened up channels to understand students' ideological status, and the virtual and hidden nature of the network alleviates students' psychological constraints in front of teachers, enabling educators and students to break the gap between generations and realize teachers. Life is equal in communication. In the new media environment, students can open their hearts, freely express their opinions, express their own ideas and opinions. Ideological and political educators in colleges and universities can not only understand students' real ideas, but also discover their ideological problems. Moreover, we can interactively discuss and communicate with them, enter the inner world of college students, and increase the trust of both sides.

\section{AdVAntages of NeW MEdia In IdEOLOGiCAL AND POLITICAL EDUCATION}

\section{A. Standardizing Students' Online Words and Deeds}

The new media is popular and popular among college students, but the quality of information is uneven, full of all kinds of hypocritical and vulgar information, which has a negative impact on students' thoughts and values. It can give 
full play to the advantages of ideological and political education in new media, help students to use new media correctly, effectively solve the problem of students not wanting to make progress and indulging in the network, and help students to make use of the network with restraint.

\section{B. It can be Easily Accepted by Students}

College students are more accustomed to use new media to obtain information, for many important social events, national policy, students are using new media to receive and spread. Therefore, the new media can be used to effectively integrate the video, text and picture resources, and promote students to accept ideological and political education more vividly and intuitively. Students need only mobile devices to study politics and ideology at any time, communicate effectively with teachers, and have flexible teaching methods, which are welcomed by students.

\section{It can Provide an Effective Platform for Ideological and Political Education}

The effective communication platform of new media is applied in the ideological and political education. Students use social tools such as WeChat and Weibo to realize instant interaction and exchange. It is beneficial for students to digest and understand the social hot spots and boring knowledge.

D. Improve the Vitality of Ideological and political education

In the new media environment, people can understand information from all over the world without leaving their homes, and at the same time they can publish their own information to every corner of the world. Everyone is not only the information maker but also the disseminator. Information publishers and information recipients can interact with each other in real time. Mass information resources and modes of communication are loved by young students. College students can not do without application computers and mobile phones in their daily study and life. New media devices, such as tablets, can be seen here. Applying the effect of new media to ideological and political education not only enriches the content of education, but also enriches the connotation of ideological and political education. Let the theme of ideological and political education, such as practicing socialist core values, be more approachable, vivid, easy to understand, enhance the appeal of education, and change the boring preaching of traditional ideological and political education. An awkward situation in which students' interest in learning is low.

\section{New Media Brings Challenges to IdeOlogical} AND POLITICAL EDUCATION IN COLLEGES AND UNIVERSITIES

Things have two sides. New media is a double-edged sword, which plays a positive role in Ideological and political education, but also has a negative impact on Ideological and political education.

\section{A. It Challenges the Authority of Ideological and Political Education}

All the time, ideological and political educators are responsible for the organization and implementation of educational activities, from educational content to educational methods to teaching activities occupy a dominant position, with a sense of authority. The emergence of new media, the breadth and speed of obtaining information by educators, and the ability of using new media affect the authoritative position of ideological and political educators. The traditional ideological and political education mainly depends on the one-way teaching of teachers, the passive acceptance of students, the relatively single way of obtaining information. Under the new media environment, the information transmission is open and flexible, and the channels for students to obtain information are broadened. Students use a variety of means of communication to obtain a wide variety of information, not only rely on teachers to teach, but also The new media put forward higher requirements for the professional qualities and abilities of Ideological and political educators. We should not only pay attention to the improvement of Ideological and political theory knowledge and inquiry ability, but also strengthen the new media elements. Cultivation and skill development.

\section{B. It can Increase the Difficulty in Organizing Ideological and Political Education Classes}

Classroom is one of the important positions of ideological and political education. The mass and sharing of new media content reduces the attraction of ideological and political education. With the popularity of mobile Internet and the emergence of smart phones, many college students have a special preference for new media. Playing with mobile phone in class and lacking effective control of network behavior increase the difficulty of organizing ideological and political education classroom. In the process of teaching, students immerse themselves in the information provided by new media, and mass thoughts and information spread rapidly through new media platforms, such as WeChat or QQ, and compete with each other in classroom teaching. Constantly crowding out the contents of the lectures of ideological and political educators in the minds and hearts of students The space for students to separate from the teacher's teaching content. In addition, students' use of new media devices such as mobile phones is not conducive to the development of their ability to analyze and solve problems. The mass and sharing of new media content contributes to the students' inertia of not thinking. Internet search is the main way for college students to solve their learning problems. There is no problem in obtaining relevant information. However, when they encounter problems, Baidu does not look at the textbooks and does not analyze them, and queries directly on the Internet. The method of obtaining the answer affects the ideological and political education into the mind and dispels the teaching effect and influence of the ideological and political education.

\section{It can Increase External Risks in Ideological and Political Education}

The new media broadens the dissemination platform of ideological and political education, extends the space-time scope of ideological and political education, and at the same time makes the environment of ideological and political education complex and increases the external risks of ideological and political education. As an open information platform all over the world, new media are filled with various cultural and ideological values. At the same time, in the era of new media, everyone can not only receive information, but 
also publish and disseminate information. Communicators can also conceal their true identity, government agencies can publish information, Western capitalist countries can promote political views and values, and illegal elements, both domestic and overseas, can spread extreme information, even among ordinary people. The public can also have no scruples in disseminating information and expressing their views. The new media contains large amount of information, including authority information, false information, vulgar information and reactionary information. American political scientist Andrew Chadwick believes that the Internet has become "a terminal tool for Western values to be exported to the world." College students' social experience is relatively shallow, their ability to distinguish information is not strong, they are in the critical period of the formation of world outlook, outlook on life and values, and they are vulnerable to the impact of different cultures and ideas. In a word, the new media not only provides convenience to people, but also tests the value judgment ability and model of college students who are not deeply involved in the world. They even shake their ideals and beliefs. Under the new media environment, various kinds of public opinion information full of negative energy spread wantonly, increasing the external risk of ideological and political education, fighting for the right to speak, seizing the position of public opinion, guiding students to grasp the direction in the information explosion and value diversification. This is undoubtedly a great challenge to the ideological and political education in colleges and universities.

\section{It can Change the Model of Ideological and Political Education}

Under the background of traditional media, ideological and political educators grasp the content and mode of Ideological and political education information, control the method, prepare the content carefully according to the textbooks, screen and check the educational information through ideological and political educators, and disseminate the educational information mainly by classroom, lecture and other scene teaching methods, supplemented by social practice and other forms. In the new media era, the environment of Ideological and political education becomes complicated, and the information dissemination under the new media is open and interactive. There is no gatekeeper for information dissemination, students can easily get all kinds of information, they can choose information independently, which changes the passive position of students under the condition of traditional media, and the traditional mode of educational communication is invalid. With the rapid development of mobile Internet technology, the rapid updating of knowledge, the strong ability of young students to accept new things, the traditional educational methods of preaching, teaching and solving their doubts are facing the transformation and innovation, which are in line with the needs of the development of the times. Ideological and political educators improve the level of new media technology, reform the discourse of ideological and political education, seek a new mode of dialogue education, give full play to students' subjective initiative, and increase their information control over students. And behavioral guidance, actively explore the educational model combined with the new media, and enhance the epoch and attraction of the ideological and political education model in colleges and universities in the new media era.

\section{Relevant Strategies of Applying New Network MEDIA TO IDEOLOGICAL AND POLITICAL EDUCATION IN UNIVERSITIES}

\section{A. Teachers' Perception of New Online Media Need to Change}

In order to give full play to the advantages of new media in ideological and political education, colleges and universities should pay attention to changing teachers' understanding of new media, encourage teachers to use new media in life and work, and skillfully use various social software to carry out effective communication with students. To promote the new media to become an important link between students and teachers. Teachers should actively contact and communicate with students, master the characteristics and ideological trends of contemporary college students, and ensure the smooth communication with students.

\section{B. We should Master Network Thinking and Network Language}

With the popularity and development of new media, network language has become a new fashion, humor, fresh personality characteristics of college students to resonate, widely spread and circulated. In order to give full play to the positive role of the new media in ideological and political education, teachers should actively understand the network language, master the interest points and language habits of contemporary college students, and bring students a sense of intimacy through the network language so as to make them interested. Willing to accept the way to carry out ideological and political education, network as a channel to help students set up scientific values and outlook on life, improve the moral and political level of college students.

\section{Construct a New Media Platform for Ideological and Political Education}

Colleges and universities should pay attention to the construction of new media ideological and political education platform for students. First of all, colleges and universities should combine the characteristics of the times and students' demands to build a red network. The content and information in the website should conform to the characteristics and life of contemporary college students, close to the needs of students, and arouse students' emotional resonance through ideological and political education platform. To provide convenient conditions for the orderly development of ideological and political education. Secondly, colleges and universities should establish a platform of communication and interaction between teachers and students, create a proactive educational environment within the campus, give play to the interactive role of the new network media, and strengthen the interaction between teachers and students through QQ, Weibo. WeChat and other carriers to promote effective communication between teachers and students Finally, teachers should fully understand the role of new media, reasonably guide students, through new media channels for students to solve life and learning problems encountered in order to attract students to actively participate in Ideological and political education. 


\section{Use New Media to Develop Targeted Teaching}

New media has been widely used in college students. Teachers should use new media to carry out targeted teaching, to understand the value orientation and ideological trends of college students, and to understand what students need. Combined with the needs of students to adopt targeted teaching methods. With the help of new media, teachers can get closer to students' reality, get to know students and improve the effectiveness and pertinence of ideological and political education.

\section{CONCLUSION}

In a word, the application of new media in Ideological and political education requires colleges and universities to integrate new ideological and political knowledge, new theories and new concepts into teaching, guide students to care about social development, strengthen the education and publicity of network laws and regulations, and standardize students'online words and deeds in accordance with their own actual situation and the cognitive laws of contemporary college students. Advocating Internet civilization and promoting the comprehensive quality of college students.

\section{REFERENCES}

[1] Xi Jinping. Speech at the National Conference on ideological and political work in Colleges and Universities [N]. People's Daily, 2016-12-09 (1).

[2] China Internet Information Center. The 39th China Internet Development Statistics report [EB / OL]. (2017-01-22) .http: / www. cac. gov. cn / 2017-01 / 22 / c _ 1120352022. htm.

[3] Andrew Chadwick. Internet Politics: state, Citizenship and New Communication Technology [M]. Beijing: Huaxia Press, 2010. 34.

[4] The document Research Office of the Central Committee of the Communist Party of China. Xi Jinping's exposition on Comprehensive deepening Reform [M]. Beijing: central Literature Publishing House, China (in Chinese).

[5] Qiu Peihuang. On Media Quality Education[M]. Sichuan:Sichuan University Press, 2004. 145.

[6] Xi Jinping. Working together for reform [N]. People's Daily 2014-8-19 (1). 